\title{
Pode um porco falar? Doença, sistemas e sacrifício no Caribe
}

Can a pig speak? Disease, systems, and sacrifice in the Caribbean

Rodrigo Charafeddine Bulamah*

*Universidade Federal de São Paulo - São Paulo, SP, Brasil

Em pós-doutoramento (bolsista Fapesp, processo n. 2019/04170-4)

rodrigobulamah@gmail.com

https://orcid.org/0000-0002-4734-7672 


\title{
Resumo
}

Este artigo discute o massacre dos porcos crioulos que teve lugar na ilha de Espanhola, particularmente no Haiti, entre finais da década de 1970 e começo dos anos 1980. Combinando etnografia e análise historiográfica, discuto, primeiramente, a trajetória de uma doença que afetou porcos domésticos em todo o globo, ameaçando criações e gerando uma série de políticas e arranjos científicos que visavam contê-la. Trato, então, das motivações culturais e políticas e os meios técnico-científicos que tornaram o massacre possível e as diferentes teorias sobre a doença para, por fim, abordar os impactos do massacre no cotidiano dos criadores rurais no Haiti. Argumentando que esse evento realizou-se, na visão de especialistas, como um sacrifício ritual que visava modernizar os sistemas de criação no Haiti, discuto as diferentes visões sobre os animais e a domesticação.

Palavras-chave: Caribe; peste suína africana (PSA); biopolítica; domesticação.

\begin{abstract}
This article analyses the creole pig massacre in Hispaniola, particularly in Haiti, that happened between the end of 1970s and early 1980s. Drawing from both an ethnographic work and a historical analysis, I first focus on the trajectory of a disease that affected domestic pigs in the whole globe and generated a series of politics and scientific assemblages to contain its spread. From there, I analyze the cultural and political motivations and the techno-scientific means that gave rise to the massacre as well as the different theories about the disease. On the last part, I discuss the impacts of the massacre in peasants' daily life, arguing that this event became, according to specialists, a ritual sacrifice that aimed at modernizing Haiti's pigs raising systems. My argument here is that this event reveals concurrent visions of animals and domestication.
\end{abstract}

Keywords: Caribbean; African Swine Fever (ASF); biopolitics; domestication. 


\section{Introdução ${ }^{1}$}

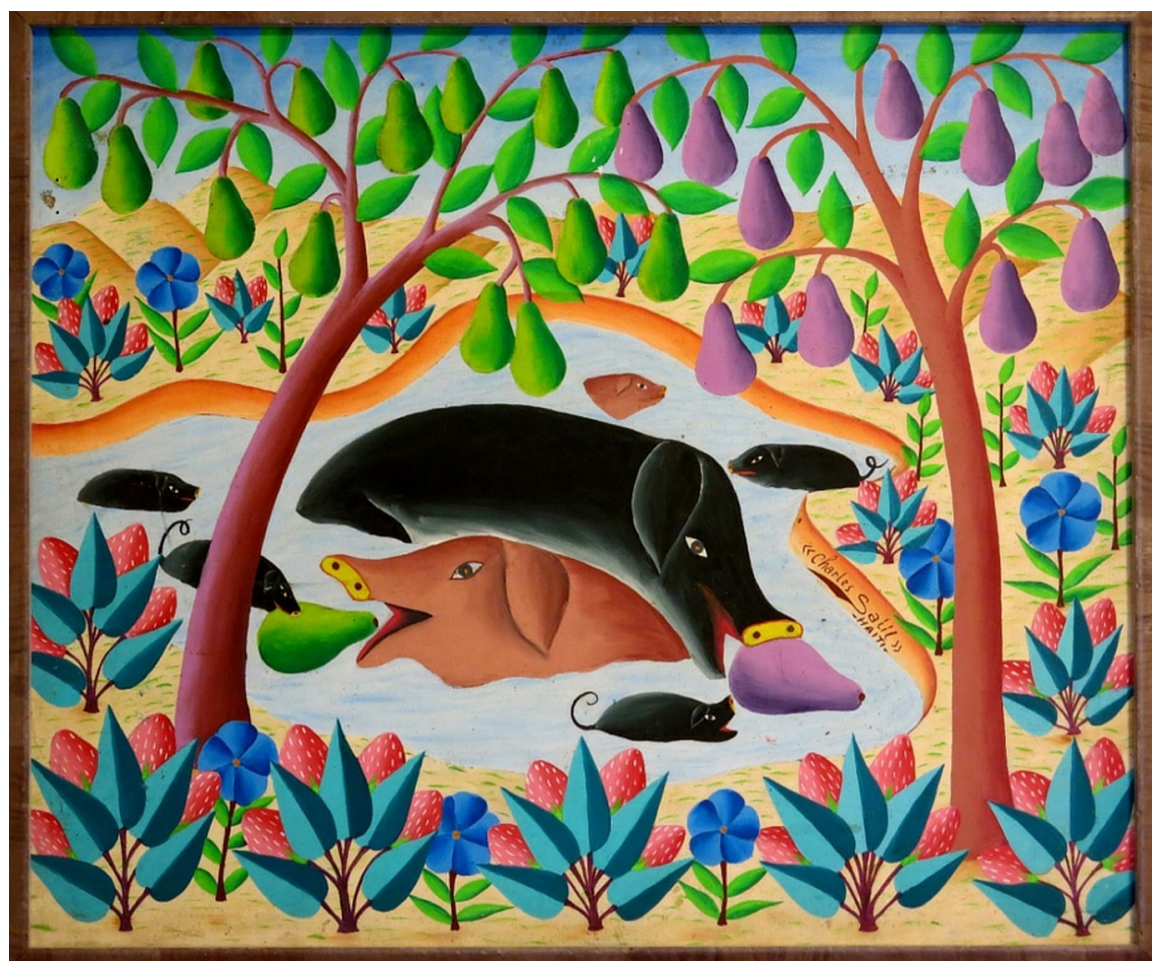

Figura 1. Sem título, Charles Saül, ca. 1970, óleo sobre tela. Coleção de Laura Wagner (imagem gentilmente cedida ao autor).

Em julho de 1978, sanitaristas, veterinários e outros agentes de órgãos internacionais do México, do Canadá e dos Estados Unidos chegaram à ilha de Espanhola, no Caribe, com o objetivo de exterminar a população local de porcos,

1 Agradeço aos pareceristas anônimos de Horizontes Antropológicos pelas sugestões, a Cleber Rocha das Neves pela revisão e a Caetano Sordi pela leitura sempre crítica e generosa. Sou grato também à equipe da Bibliothèque Haïtienne des Frères d'Instruction Chrétienne (BHFIC), em Porto Príncipe, e aos funcionários da Fondren Library da Universidade Rice, em Houston, pelo auxílio no acesso à documentação que analiso ao longo do texto. 
denominados crioulos (kreyòl), controlando, assim, a possível difusão de uma doença suína de origem africana pelo continente americano. Começaram pela República Dominicana, eliminando a totalidade de porcos do país e avançando em direção ao Haiti num espaço de $15 \mathrm{~km}$ fronteira adentro. Contudo, logo alegaram que a medida preventiva havia sido insuficiente. Em 16 de novembro de 1981, o programa tomou conta de todo o Haiti. A eliminação seletiva de animais já havia sido praticada pontualmente em países como Portugal, Espanha, Cuba e Brasil com a finalidade de conter a dispersão de doenças. Porém, aquela seria a primeira vez que tal prática ganharia a dimensão de estratégia prioritária no combate a enfermidades animais, sendo aplicada a toda a extensão do território nacional ou, no caso em questão, a uma ilha inteira.

Exatos dois anos depois, em novembro de 1983, durante a $10^{\mathrm{a}}$ Reunião do Comitê de Coordenação do Projeto de Erradicação da Peste Suína Africana e de Desenvolvimento da Criação de Porcos (PEPPADEP, na sigla em francês), especialistas de agências como a Organização das Nações Unidas para Alimentação e Agricultura (FAO), a Organização dos Estados Americanos (OEA), o Banco Interamericano de Desenvolvimento (BID) e a Agência dos Estados Unidos para o Desenvolvimento Internacional (USAID), de universidades como a do estado da Geórgia, nos Estados Unidos, e funcionários de governo haitianos e estrangeiros celebravam o sucesso da política de extermínio dos porcos crioulos e discutiam as últimas medidas a serem tomadas para a efetiva declaração do Haiti como país livre da peste suína africana (PSA). Entre essas medidas estavam a busca por animais que foram escondidos pelos camponeses, a caça a porcos ferais que porventura pudessem servir como hospedeiros para o vírus, a introdução de animais sentinelas para mapear áreas onde a doença ainda poderia estar presente e a refundação das práticas e dos ambientes de criação para o seguinte repovoamento do país com uma espécie estrangeira. "O programa no Haiti”, afirmava um entusiasmado Dr. Quentin M. West, do Instituto Interamericano de Cooperação para a Agricultura (IICA-OEA), "servirá como um exemplo para a resolução de problemas em outros países do hemisfério e os ajudará a progredir" (10th Coordinating..., 1983, p. 1, tradução minha).

O impacto do massacre nas economias locais foi imenso, algo que, de fato, não foi ignorado pelos participantes daquela reunião que se estendeu da manhã do dia 14 de novembro de 1983 à tarde do dia 16. Porém, mesmo frente a tais "sacrifícios dolorosos do povo haitiano", o Haiti seria recompensado ao ajudar 
nesse projeto de biossegurança por meio da criação de uma barreira sanitária "contra pragas naturais capazes de colocar em perigo economias de todo o hemisfério" (10th Coordinating..., 1983, p. 40, tradução minha). O agrônomo e secretário de Estado para o desenvolvimento rural do Haiti, Luckner St-Dic, ao anunciar o fim da primeira fase do programa - o extermínio dos porcos crioulos - "destacou, contudo, a importância do pan-americanismo que fez [o país] sacrificar sua economia a fim de prevenir a difusão de uma praga pelo continente". Notável também, segundo o agrônomo, era a "fé do povo haitiano em seu governo ao aceitar tal projeto; ambos, o povo e o governo, mantiveram suas promessas e são, os dois, guerreiros eméritos" (10th Coordinating..., 1983, p. 1, tradução minha).

A primeira vez que ouvi falar sobre o massacre dos porcos crioulos foi durante meu primeiro trabalho de campo no norte do Haiti, em 2012. À época eu vivia no povoado rural de Samson, parte da comuna de Milot, e enquanto conversávamos sobre animais de criação, madame André, a dona da casa onde eu vivia, trouxe à tona a história do massacre. Foi no começo dos anos 1980, me contou ela, quando um grupo de pessoas chegou ao povoado bradando repetidamente o nome do programa de erradicação: "PEPPADEP! PEPPADEP!" Ofereciam 40 dólares haitianos pelos porcos maiores e 20 pelos pequenos. ${ }^{2}$ Os criadores, então, entregavam seus porcos aos oficiais que os matavam com um golpe de bastão ou com a administração de uma injeção e, é importante destacar, retornavam os animais abatidos aos donos. Ao cabo de alguns meses, espécimes hiperselecionados começaram a chegar ao país. Pouco adaptados às regiões tropicais e de difícil cuidado, os "porcos estrangeiros" ou "brancos" (kochon blan), como ficaram conhecidos, não tinham os mesmos usos e costumes dos porcos crioulos.

Era todo "um outro sistema [sistèm]", completou madame André, "os porcos que temos hoje são como os brancos [blan], têm essas orelhas longas, são magros, cavam fundo por todos os lados e sua carne não é tão saborosa". Foi a partir do relato de madame André que comecei a ir atrás dos vestígios deixados por esses animais crioulos e dos efeitos de suas ausências. De fato, os

2 O dólar haitiano (HD) é uma unidade monetária fictícia utilizada em transações econômicas cotidianas. Há uma cotação fixa estabelecida com a outra moeda local, o gourde (HTG), em 5:1. Ambas são frequentemente cotadas com base no dólar estadunidense e, durante meu trabalho de campo, a cotação girou em torno de 1 USD:50 HTG:10 HD, chegando, em 2016, numa proporção de 1:60:12. Enquanto o gourde é impresso em papel moeda, o dólar haitiano tem as características de uma “moeda imaginária” (ver Neiburg, 2016). 
moradores rurais do norte do Haiti compreendem sua relação com esses animais por meio da categoria nativa de sistema, fazendo uma diferença entre o sistema dos porcos crioulos (sistèm kochon kreyòl) e o sistema dos porcos brancos (sistèm kochon blan). Nesse sentido, a partir do massacre e da introdução de novas variedades animais, um sistema passava a ocupar o lugar de um outro, gerando um conjunto de implicações que, como veremos, redefiniram a vida social em todo o país. Um dos objetivos deste texto é somar esforços para repensar a ideia de "sistema domesticatório", originalmente proposta por Digard $(1988,1999)$ e discutida recentemente por autores como Sautchuk (2018) e Deturche (2017). A ideia é pensá-la aqui à luz do que os próprios moradores rurais entendem por "sistema dos porcos".

O episódio, cabe ressaltar, povoa também o imaginário acadêmico sobre o Haiti. De fato, o massacre constitui um dos maiores dramas de consciência de liberais norte-americanos, sendo muitas vezes referido como um exemplo das políticas imperialistas dos EUA no Caribe. Porém, talvez por serem apenas porcos, pouco se sabe sobre esses animais, sua história, suas práticas e seus comportamentos. Comum aos trabalhos acadêmicos que tratam do massacre é a ênfase no fato de que os porcos crioulos operavam como poupança dentro da economia camponesa, servindo como reserva de capital para momentos de dificuldade, de cerimônia ou de celebração. Poucos autores vão além dessa evidência, enfatizando a dimensão estrutural, mas sem explorar a fundo as motivações e consequências culturais e políticas e os meios técnico-científicos que pautaram o massacre. ${ }^{3}$

De fato, porcos, como outros seres, convivem cotidianamente com pessoas e tomam parte na produção de mundos sociais, definem ritmos de vida multiespécies, corporificam valores, temporalidades, significados, compõem paisagens e histórias comuns e carregam consigo sinais e possibilidades de autonomia ou de sujeição. Na cadeia de eventos que culminou no massacre dos porcos crioulos, animais, veterinários, vírus, saberes culinários, técnicas laboratoriais e práticas de criação interagiram em diferentes escalas e produziram diferentes efeitos. O encontro desses agentes e práticas não é incomum ao longo da história (ver, por exemplo, Mintz, 1985; Mitchell, 2012; Wolf, 2002), mas sua interação nesse momento e local específicos nos coloca problemas interessantes. Em

3 Na literatura especializada, os que se dedicaram ao tema foram Abbott (1988, p. 241, 274-275), Farmer (1992, p. 37-41), Smith (2001, p. 28-30) e Richman (2005, p. 49-51). 
um texto recente (Bulamah, 2019), analisei a jornada dos porcos até o Caribe e o modo como esses animais influenciaram os ritmos da colonização e da plantation e participaram ativamente da criação de espaços de autonomia de grupos escravizados; me interessa agora buscar o que motivou o massacre dos porcos na segunda metade do século XX e suas consequências. Como esses agentes e noções distintas de animalidade, de vida e de doença circularam e afetaram uns aos outros? Que tipo de explicação é possível esboçar para trazer à tona essas conexões, suas motivações e consequências? Ou ainda, que história é possível contar se olharmos para os porcos? ${ }^{4}$

\section{Porcos domésticos, portadores inaparentes e vírus mortais}

As décadas de 1960 e 1970 foram tempos agitados nos mares caribenhos. A Revolução Cubana de 1959 teve repercussões importantes em todo o globo, incidindo de modo particularmente intenso no Caribe, na América Latina e nos Estados Unidos. Enquanto isso, projetos independentistas se consolidavam em ilhas e territórios como Jamaica (1962), Trinidad e Tobago (1962), Barbados (1966), Guiana (1966), Granada (1974), Santa Lúcia, Dominica e São Vicente e Granadinas (1977-1979) e, na década de 1980, Antígua e Barbuda (1981), Belize (1981) e São Cristóvão e Névis (1983). Adensou-se, com isso, uma reestruturação das antigas alianças e influências e, aos poucos, os Estados Unidos ganharam controle sobre o Caribe, afastando as potências europeias ao mesmo tempo que bloqueavam e combatiam a difusão de propostas revolucionárias, anti-imperialistas e socialistas na região (Palmié; Scarano, 2011; Scott, 2014). Localmente, elites econômicas e governos nacionais aproveitaram-se disso para colocar em

4 De aproximações entre movimentos libertários e animais no século XIX, como no pioneiro trabalho de Nádia Farage (2011, entre outros), a animais de criação em contextos rurais (Andriolli, 2011; Pereira, 2012; Sordi, 2015; Sordi; Lewgoy, 2017) e indígenas (Garcia, 2011; Vander Velden, 2012), para citar apenas alguns, há uma crescente literatura dedicada às relações multiespécies questionando a fundo premissas disciplinares antropocêntricas e a própria excepcionalidade humana. Um marco importante nos estudos sobre animais é o clássico trabalho de Keith Thomas (1996), além das coletâneas recentes organizadas por Cassidy e Mullin (2007) e Few e Tortorici (2013). Além desses trabalhos, o livro de Mitchell (2012) me ajudou a pensar a própria forma como contar essa história e foi dali que tirei a inspiração para o título deste artigo. Ver ainda os volumes editados das revistas Vibrant (2016), Horizontes Antropológicos (2017) e R@U - Revista de Antropologia da UFSCar (2015). 
prática suas propostas, negociando com os EUA a manutenção de certos privilégios comerciais e políticos em troca de apoio a medidas e regimes autoritários, entre os quais o de François "Papa Doc" Duvalier, no Haiti. Entre os efeitos da Revolução Cubana esteve também a mudança da dinâmica do turismo na região, com Cuba perdendo o protagonismo e outras ilhas experimentando um intenso e crescente fluxo de pessoas, mercadorias e capitais (Plummer, 1990).

Foi nessa época que Milot passou a fazer parte de uma rota turística caribenha e cruzeiros atracavam no porto de Cabo Haitiano com os turistas seguindo então para o vilarejo, a fim de visitar o Palácio Sans Souci e a Cidadela, duas construções emblemáticas do pós-independência (Bulamah, 2018). Milosianos mais velhos lembram-se desse momento e do calendário semanal de chegada dos navios. Moradores de povoados rurais, por exemplo, mantinham criações de cavalos que alugavam para o transporte dos turistas até a Cidadela. Ao lado desse estímulo ao turismo, outras medidas ganhavam corpo, como negociações sobre a exportação de lixo tóxico dos EUA para o Haiti e a montagem de uma fábrica de extração de plasma sanguíneo em Porto Príncipe. ${ }^{5}$ Contudo, essa nova onda de investimentos e as riquezas produzidas com o turismo contrastavam com a situação socioeconômica geral do país.

O Haiti estava à época sob o controle de um regime autoritário, com François Duvalier à frente do Estado e, posteriormente, com seu filho, Jean-Claude "Baby Doc" Duvalier, que assumiu o poder em 1971, com apenas 19 anos de idade. Seu governo foi marcado pela continuidade do regime de terror e violência na esteira do governo do pai e, particularmente, pela consolidação de uma relação predatória com o campesinato, ao mesmo tempo que o país se abria a políticas neoliberais. ${ }^{6}$ Perseguições políticas e opressões socioeconômicas fizeram avançar

5 Sobre o lixo tóxico, ouvir o editorial do importante agrônomo e jornalista Jean Dominique, na Rádio Haïti-Inter, emissão do dia 20 de outubro de 1980 (Editorial..., 1980). Sobre a fábrica de plasma, ver Richard Severo (1972).

6 A taxação da produção camponesa, particularmente do café, representava já desde muitas décadas a principal fonte de rendimentos do governo, encontrando uma elevação considerável durante o regime de François Duvalier (de 27\%, em 1953, para 37\%, em 1969). O objetivo, como mostra Trouillot (1990, p. 154), era o de beneficiar monopólios de exportação e criar uma base de apoio local através do favorecimento de especuladores. Nos arquivos do tribunal (Tribunal de Paix) de Milot, encontrei inúmeras ações que revelavam a crescente fiscalização da produção e da preparação do café por agricultores e mercadoras durante o governo ditatorial. Colher grãos verdes demais ou secá-los ao chão eram delitos puníveis com multas ou até mesmo a privação da liberdade. 
a busca de refúgio e as chamadas boat people ganhavam a costa de outras ilhas caribenhas e dos EUA, passando a figurar também em manchetes de jornais estadunidenses e haitianos. Internamente, o governo fazia pressão sobre jornalistas e ativistas políticos, além de combater seus opositores, taxando-os de "inimigos da Revolução", comunistas ou kamoken, em referência ao remédio de gosto amargo usado nos tratamentos contra a malária. Ao criar e explorar conflitos políticos nacionais e globais, Duvalier produzia efeitos importantes na manutenção da proximidade com os EUA e na própria permanência de sua linhagem no poder.?

Nos anos 1970, entretanto, um outro inimigo, este muito mais silencioso, ganhava terreno no Caribe e preocupava particularmente autoridades, políticos e especialistas dos EUA: um patógeno que afetava de modo incomum as criações de porcos domésticos. "Ele parece ter existido em porcos selvagens nativos da África por um longo tempo", descreveu, em 1971, o microbiologista William R. Hess, "pois com os suínos estabeleceu uma relação ideal de parasita-hospedeiro na qual uma infecção prolongada ocorre sem sinais de enfermidade" (Hess, 1971, p. 2, tradução minha, grifo meu). Essa doença endêmica à África Oriental começou a ser reportada, de fato, a partir do transporte de porcos domésticos europeus às colônias africanas, em princípios do século XX. Sua presença foi primeiro descrita pelo veterinário colonial inglês R. Eustace Montgomery (1921), que à época trabalhava no protetorado da África Oriental Britânica (posterior protetorado e colônia do Quênia). A similaridade com outra doença, a peste suína clássica (PSC), conferiu-lhe o nome de peste suína da África Oriental (PSAO).

$\mathrm{O}$ vírus tinha particular atração por tecidos internos e a doença era percebida, a princípio, como uma forma de pneumonia que afetava também o canal digestório. Infectando indiscriminadamente porcos de diferentes idades e tanto machos quanto fêmeas, o animal doente costumava apresentar sintomas de extremo cansaço, mostrando-se abatido, o rabo pendendo involuntariamente e o ventre retraído, além da perda da fome, uma sede incomum e uma

7 O antropólogo Louis Herns Marcelin (2012, p. 260-261) descreve o peso que termos como kominis ("comunista") e kamoken tinham entre as comunidades rurais e o modo como tais classificações eram associadas a forças malignas que corrompiam os jovens, muitos deles estudando nas cidades e constituindo uma forte oposição ao regime ditatorial. Ademais, como mostram Kelly e Kaplan (2001), a influência imperial estadunidense ocorria, nesse momento, menos através de um governo direto do que pelo estímulo a movimentos nacionalistas e descolonizadores que se alinhassem à sua política externa. 
febre acentuada que poderia exceder os 40 (Montgomery, 1921, p. 161). A partir da constatação desses primeiros sintomas, em não mais de 48 horas, o animal sucumbia. A doença começou a se fazer notar em criações próximas a áreas onde viviam javalis-africanos (Phacochoerus sp.).

Na África Oriental Britânica, espécimes domésticos europeus eram destinados exclusivamente ao consumo dos colonos e, não havendo mercado, a circulação dos porcos se restringia a um circuito simples: iam das fazendas à fábrica local de toicinho, a única na região. Como nota Montgomery (1921 p. 160, tradução minha), "cada surto [da doença] parece ter surgido de forma independente. Todos os porcos domésticos vivendo agora no protetorado foram originalmente importados do exterior. Não há nenhuma espécie indígena ao país ou em posse de nativos na África Oriental Britânica." Isso se explica pelo fato de que, até 1920, a região era ainda parte do Sultanato de Zanzibar e porcos, como outras espécies de além-mar, serviam à adaptação de colonos e agentes coloniais, numa sorte de "europeização das paisagens", na expressão precisa de Alfred Crosby (1986). ${ }^{8}$ Esses animais viviam em liberdade nos terrenos, cuidados por pastores nativos, e arrebanhados à noite para lotes cercados, com a finalidade de serem alimentados e para evitar ataques de animais selvagens.

Apesar da presença considerável de javalis-africanos em todo o protetorado, naquele período, a associação entre eles e a difusão da doença era algo circunstancial, menos embasado na evidência da presença do vírus ou em estudos sobre os possíveis portadores do que em observações epidemiológicas. De todo modo, a julgar pelos 15 surtos da doença relatados na região, até finais de 1915, e outros dois na África Oriental Alemã, aquela era uma infecção fatal, apresentando uma taxa de mortandade da ordem dos 98,9\% (Montgomery, 1921, p. 160).

Entre 1910 e 1916, Montgomery levou a cabo experimentos de inoculação do vírus em diversos animais domésticos, entre suínos, bovinos, caprinos, cães e coelhos, observando de modo controlado os estágios de incubação e suas reações. Seguindo os postulados de Henle-Koch, formulados em finais do século XIX, os experimentos eram feitos através da injeção de fragmentos do sangue de um animal contaminado em outro, de mesma espécie ou de

8 As estirpes e cruzamentos de porcos presentes no protetorado britânico eram quatro: Berkshire, Longblack, Tamworth e Seychelles, não havendo diferenças quanto à suscetibilidade à doença (Montgomery, 1921, p. 162). 
espécie diferente, a fim de se observar as possíveis reações e a permanência do vírus no sistema sanguíneo de cada grupo. ${ }^{9}$ Somente nos porcos domésticos notavam-se reações infecciosas e, invariavelmente, a morte dos animais (Montgomery, 1921, p. 162-165). Inoculações também foram empreendidas em javalis-africanos e porcos-do-mato-africanos (Potamochoerus sp.), capturados por fazendeiros locais ou de colônias vizinhas, como Uganda. Buscava-se domesticá-los a fim de criar um ambiente propício para a observação das reações, muitas vezes sem sucesso, pois a maioria dos animais morria antes que qualquer reação fosse notada, resultado do confinamento e do novo ambiente artificial e cruel a que eram submetidos. Contudo, os poucos que sobreviviam ou que eram capturados jovens o suficiente para se aclimatarem ao confinamento não apresentavam sinais da doença. Assim, conclui Montgomery (1921, p. 188, tradução minha), porcos-do-mato e javalis-africanos "não reagem à inoculação como os porcos domésticos; eles não manifestam nenhum sintoma e são presumidamente imunes. Parece, contudo, que a imunidade não é tão completa quanto em bois e carneiros e que o vírus pode sobreviver no sangue do porco selvagem por um certo tempo."

Não demorou muito para que o vírus alcançasse outras rotas e ganhasse as criações da Europa. Em 1957, a doença chegou a Portugal e, só a partir dali, começou a chamar a ampla atenção de instituições nacionais e supranacionais (Manso Ribeiro et al., 1958). As formas de transmissão aos porcos domésticos, porém, permaneciam um mistério (Hess, 1971, p. 3). Pesquisas e experimentos difundiram-se, então, para além dos territórios africanos, e simpósios nacionais e internacionais, congressos técnicos, reuniões e publicações tornaram-se cada vez mais numerosos, concentrando-se, de um lado, na investigação sobre a patogenia do vírus, sua origem e evolução e, de outro, no estudo de sua estrutura, de sua composição e de suas formas de replicação. ${ }^{10}$

9 Tentativas de propagação do vírus em outros animais tornaram-se comuns a partir de então, por três razões principais: i) encontrar um animal de laboratório menos dispendioso; ii) determinar se outras espécies eram capazes de hospedar o vírus; e iii) observar possíveis modificações em outros hospedeiros (Hess, 1971, p. 17). Sobre o tema do contágio, ver ainda Lévi-Strauss (2006, especialmente, p. 16-17) e Farage (2011).

10 Analisando uma compilação bibliográfica que abarca os anos de 1921 a 1965 (Balassa, 1966), é possível notar um crescente número de publicações especializadas a partir de 1957, quando a doença chega à Europa. 
Em 1960, após pesquisas feitas no Quênia, descobriu-se um modo de detectar o vírus por meio de um teste in vitro, concretizando a possibilidade de diagnóstico da peste suína africana e a diferenciação de sua variante clássica (Malmquist; Hay, 1960). Data de 1961 a primeira reunião da Organização das Nações Unidas para Alimentação e Agricultura (FAO) inteiramente dedicada à questão, algo que se tornou recorrente na forma de congressos anuais sobre $o$ tema, reunindo diferentes especialistas e agentes de governo e resultando em publicações e resoluções a serem seguidas por países afetados. Se, como mostra Bruno Latour (1988, p. 123, tradução minha, grifo original removido), com as descobertas de Pasteur sobre germes e seres infecciosos na França do final do século XIX, uma "doença não era mais um infortúnio privado, mas uma ofensa à ordem pública", para o caso da peste suína africana, a doença ganhava dimensões mais amplas e tornava-se uma ofensa à ordem global.

Em pouco tempo, a enfermidade passou a ser definida simplesmente como "peste suína africana" (PSA) ou, em uma homenagem àquele que primeiro a descreveu, "doença de Montgomery". Pelo que se tem documentado, a partir de 1960, o vírus se espalhou pela Europa, indo de Portugal à Espanha, chegando aos Pirineus e à Bretanha e, posteriormente, em 1967, aos arredores de Roma (Destruction of pigs..., 1967). Os surtos eram na maioria dos casos respondidos com programas drásticos de erradicação dos porcos infectados, mas notava-se uma diminuição da patogenia do vírus e as reações das populações de porcos já não eram tão marcantes como nas primeiras observações (Sánchez Botija; Polo Jover, 1964). Mesmo assim, a mera presença do vírus causava alarde em autoridades, temendo a resiliência ou readaptabilidade do patógeno ou de seus vetores. Como nota o microbiologista William R. Hess, em 1971, apesar das mortes pontuais que ocorreram até aquela data, "a PSA está ainda presente em Portugal e na Espanha e foi mais uma vez relatada na Itália” (Hess, 1971, p. 2, tradução minha).

Hess tornou-se o maior especialista na peste suína africana nos EUA e seu pequeno estudo monográfico é um dos mais detalhados trabalhos sobre o assunto. O texto traz um debate bibliográfico sobre a doença, compilando pesquisas feitas até finais da década de 1960. Desde as investigações iniciais, o modo de transmissão da doença havia sido o principal enigma com o qual se confrontavam os cientistas e permanecia sendo, como nota o microbiologista, "o ponto mais fraco em nosso conhecimento da epidemiologia veterinária da PSA" (Hess, 1971, p. 27, tradução minha). $O$ vírus apresentava grande estabilidade no sangue, nas excreções 
e nas vísceras dos porcos contaminados e era, por isso, altamente contagioso entre os espécimes domésticos em razão da prática de se administrar carne de porcos a animais da mesma espécie. Ademais, já desde meados da década de 1960, pesquisadores apontavam para a possibilidade de que "portadores inaparentes", sobretudo carrapatos, pudessem ser os responsáveis pela difusão da infecção em zonas de contato entre espécies selvagens e domésticas e em fazendas de criação extensiva. No entanto, exatamente por essas incertezas, surgiram um conjunto de controvérsias tais como as diferentes teorias sobre o contágio, além de hipóteses sobre possíveis relações com outras doenças animais ou humanas.

Nessa guerra ao vírus da peste suína africana, a ideia de erradicação dos espécimes doentes (stamp out) passou a ser algo prescrito:

Since satisfactory immunizing agent for ASF is not available, rapid detection and elimination of infected and exposed animals is the procedure employed to halt the spread of the disease. The effectiveness of this "stamping out" method depends to a large extent upon the speed with which it is initiated. Rapid diagnosis is therefore essential. (Hess, 1971, p. 25).

Mais importante do que certezas com relação ao que era a doença, as respostas ao seu avanço foram dando-lhe o contorno de uma enfermidade global a ser contida a todo custo. No caso da febre aftosa na Inglaterra, discutido com rigor pela historiadora Abigail Woods (2004), não foi um conjunto estabelecido de conhecimentos que levou a uma série de ações globais para conter sua propagação, mas exatamente a existência de diversas teorias sobre a doença que, à medida que se difundiam, "manufaturaram", como diz Woods, a própria doença. Quanto à PSA, por sua vez, a produção da doença e as medidas de contenção acabaram resultando também na criação de uma representação específica sobre o que eram os animais e de como deveriam se portar os criadores.

Na década de 1970, a doença se espalhava pelo Caribe e chegava também a países da América do Sul. Ao ser diagnosticada em Cuba, em 1971, aplicou-se o método de eliminação seletiva. ${ }^{11}$ Em 1978, surtos foram reportados na

11 A peça de teatro Manteca do dramaturgo cubano Alberto Pedro Torriente (2005), que estreou em Havana em 1993, é um retrato notável do "período especial" e traz uma reflexão poética sobre o lugar dos porcos. 
República Dominicana e no Brasil, separados por uma diferença de alguns meses. Comum entre esses dois casos era o fato de o contágio ter sido associado à proximidade com aeroportos e ao consequente acesso de porcos a dejetos contaminados vindos de países estrangeiros. ${ }^{12}$ Além disso, as práticas de criação nos dois países eram bastante descentralizadas e desenvolvidas, sobretudo, em pequenas propriedades na zona rural ou em periferias urbanas, favelas e bairros pobres (ver Sánchez Díaz, 1980, p. 55). ${ }^{13}$ Entendia-se que essas práticas de criação eram retrógradas e insalubres, favorecendo a justificativa de que o extermínio dos porcos serviria também para a modernização das fazendas e das formas de interação com os animais. Exatamente por essa liberdade na criação e pelo fato de que o vírus se mantinha ativo no sangue e nos tecidos dos porcos mesmo após a morte, ganhou corpo a hipótese da contaminação por ingestão de produtos e fragmentos de origem animal oriundos dos depósitos de lixo de aeroportos. Mas muitas ainda eram as incertezas.

Enquanto o vírus da peste suína avançava por criações em todo o globo, multiplicavam-se também as pesquisas e a circulação internacional de especialistas, resultando em uma inflação de hipóteses sobre a doença e o comportamento do vírus. Das coletas de materiais em campo, passava-se às pesquisas em laboratórios para, então, em seguida, publicar os resultados em periódicos da área e participar de seminários e reuniões internacionais, muitas delas registradas em atas e colocadas à disposição de ministérios e institutos nacionais e internacionais. ${ }^{14}$ Multiplicavam-se também as notícias de jornal com relatos de veterinários e biólogos, tornando públicos e difundindo os resultados e as hipóteses das pesquisas.

12 Ver Mendes Serrão (1980, p. 43), Orlando Sánchez Díaz (1980, p. 56) e Moura et al. (2010). A tese de doutoramento de Francisco Viana (2004) mostra por meio de uma análise de diferentes materiais, de artigos especializados a depoimentos, que o aparecimento da doença no Brasil foi acompanhado por uma série de mal-entendidos e ações descoordenadas, gerando desconfianças e rumores e afetando particularmente os pobres e as criações de fundo de quintal. Diferentes versões sobre a entrada da doença no país são apresentadas e discutidas pelo autor.

13 É provável que os sistemas descritos por Sánchez Díaz (1980) fossem comuns também às criações em algumas regiões do Haiti, como pude inferir a partir dos relatos de camponeses da região norte. Pode-se consultar ainda a descrição das práticas de criação em Groupe de Recherche pour le Développement (1981).

14 Entre as reuniões da FAO mencionadas acima, são exemplares as publicações aqui referidas, como Hess (1971) e Callis (1980), passando também por diversos artigos publicados em revistas especializadas como o "Boletim do Escritório Internacional de Epizootias" (Bulletin de l'Office internacional des épizooties). 
Muitas dessas notícias vinham ainda acompanhadas por descrições de surtos e pela difusão de imagens de porcos doentes ou mortos. ${ }^{15}$ Similar ao que ocorria no final do século XIX na França, não era a partir da ignorância que os cientistas formulavam suas opiniões, mas de um excesso difuso de conhecimento. A incerteza implicava, de fato, que tudo era plausível. Assim, tal como no momento de constituição da saúde pública na Europa, "se qualquer coisa pode causar uma enfermidade, nada pode ser ignorado; é necessário estar apto a agir de uma só vez contra tudo e em todos os lugares" (Latour, 1988, p. 20, tradução minha). Entre as décadas de 1970 e 1980, esse parece ter sido o princípio que resultou nas diversas frentes de ação contra a peste suína africana nas Américas e no Caribe. ${ }^{16}$

\section{Teorias alternativas do contágio}

Voltando ao norte do Haiti, poucas pessoas com quem conversei lembram-se de terem seus animais afetados por alguma doença similar àquela que veterinários afirmavam se espalhar pelo Caribe. Foi em uma notícia publicada em 27 de fevereiro de 1981, no importante jornal haitiano Le Nouvelliste, que encontrei a informação de que a peste avançava sobre os porcos, "sendo poucas as regiões onde os camponeses não se queixam de ter perdido uma parte ou a totalidade de sua criação de porcos" (Groupe de Recherche pour le Développement, 1981, tradução minha). Entretanto, em razão da sua origem, das práticas de criação e do longo tempo de adaptação ao lugar, é possível que os porcos crioulos fossem - diferentemente das espécies hiperselecionadas dos contextos industriais

15 Ver os relatos e as imagens que circularam na imprensa brasileira entre fins de 1970 e começo de 1980 recolhidos por Viana (2004). Algumas dessas publicações tinham ainda o claro objetivo de convencer a população sobre o perigo da doença e a importância do extermínio dos animais, como a publicação da USDA em conjunto com a USAID e a FAO lançada na República Dominicana (Mark; Chain; Ellis, 1981).

16 Um outro tema que dividia a atenção da opinião pública na região, particularmente nos EUA, era a chegada de migrantes haitianos aos Estados Unidos. Por economia de espaço, não pude tratar disso com atenção neste texto, mas em minha tese de doutoramento (Bulamah, 2018, cap. 3) discuto alguns documentos que apontam para a hipótese de uma zoonose por meio de uma aproximação entre a peste suína africana e as discussões iniciais sobre a AIDS, doença à qual a população haitiana foi injustamente considerada como um grupo de risco e que, junto com hemofílicos, homossexuais e heroinômanos, formavam o que os Centros de Controle de Doenças dos EUA (CDC) nomeou "4 H-s". 
- imunes ao vírus, tais como os porcos selvagens e os javalis-africanos descritos por Montgomery (1921). Observações distintas apontam exatamente para isso.

Já na década de 1950, Alfred Métraux (1951, p. 95, tradução minha) faz a seguinte observação ao tratar dos porcos na região de Jacmel, no sudeste do país: "Os porcos que vemos soltos perto das casas possuem o dorso espinhoso, a pele cheia de carapaças e longas pernas, o que os faz parecer javalis, como muitos viajantes notaram." Em 1978, quando os porcos do Vale do Artibonite, região central do país, foram diagnosticados com a infecção, destaca o antropólogo Paul Farmer (1992, p. 37, tradução minha) que, “curiosamente, [...] poucos porcos haitianos morreram. Alguns veterinários acreditaram que a razão poderia ser o fato de que os kochon planch, como eram denominados os porcos haitianos, se tornaram particularmente resistentes à doença." ${ }^{17}$ É possível considerar ainda a hipótese de que as linhagens virais que chegaram ao país tivessem um potencial patogênico menor, produzindo um impacto reduzido e favorecendo o desenvolvimento da imunidade e inclusive a recuperação de animais doentes em um curto ou médio prazo - algo observado, por exemplo, nos surtos que ocorreram no Brasil (Viana, 2004, p. 147).

Em Milot, para muitos interlocutores, havia outras razões por trás do extermínio dos porcos. Para alguns, o massacre foi motivado tanto pela razão imperialista dos Estados Unidos, que buscava lucros com a exportação de seus próprios espécimes ao Haiti, quanto pela ganância e pela falta de solidariedade de Jean-Claude Duvalier para com a população. "Mataram os nossos [porcos], os da gente desafortunada [malere]" - contou-me um senhor de Milot, enfatizando também uma tensão de classe - "para venderem os deles aqui. Mas nós não conseguimos encontrar os porcos estrangeiros. Trouxeram alguns, mas só os grandes senhores [gwo nèg] é que tiveram acesso."18

17 Bernard Diederich (1985, p. 16) nota ainda que, "among villagers discussing the pig eradication program, some said it was unnecessary, that there had been no disease, that it was all a plot. After all, their black pigs had lived for 500 years under extremely poor conditions and had become immune to most diseases". Um dos poucos pesquisadores que parece discordar dessas observações é o antropólogo Gerald Murray, que afirma, em um verbete sobre o massacre, que 600 mil porcos morreram da peste suína em todo o país entre o final da década de 1970 e começo de 1980 . Contudo, o autor não fornece nenhuma referência etnográfica ou documental e discorda de visões que questionam o potencial nocivo do vírus e a própria necessidade do massacre. Ver Gerald Murray ([2016]).

18 Algo similar foi relatado a Farmer (1992, p. 37), que destaca: "Some peasants were sure there had been no swine fever, that the entire epidemic was a sham tagged so that the North 'Americans could make money selling their pigs."' 
A essas explicações soma-se outra que não nega a existência de uma doença, mas identifica nela uma origem distinta. A doença que alguns interlocutores me relataram havia se propagado por aviões e helicópteros que sobrevoavam o país e dispersavam uma substância em pó sobre as parcelas e povoados rurais, atingindo particularmente os porcos, deixando-os doentes. Aviões e helicópteros foram, de fato, utilizados por autoridades envolvidas no PEPPADEP, sobretudo para localizar porcos ferais e espécimes que porventura houvessem sido escondidos por criadores. ${ }^{19} \mathrm{O}$ massacre seria a consequência inevitável desse envenenamento em massa. Com efeito, o emprego de pós é algo comum entre as práticas mágicas populares na região, conhecido como kout poud (lit. "golpe de pó"), e tais artefatos podem ser facilmente encontrados em mercados especializados, como lojas ou pequenas tendas em mercados mais amplos, como é o caso do Grand Marché, em Cabo Haitiano. Confeccionado com materiais distintos, como animais silvestres, raízes, frutos ou alguma combinação de elementos, o pó é sobretudo um veículo mágico que, dependendo da intencionalidade, afeta a pessoa ou o animal por meio de um efeito de contágio, causando alteração de humor, infortúnio, doença, azar ou morte.

Em meio a esse conjunto distinto de explicações, o massacre tomou proporções gigantescas e, segundo o jornalista e agrônomo haitiano Fritz Deshommes (2006, p. 65, tradução minha), que acompanhou de perto o PEPPADEP, "não acreditávamos que o Estado haitiano era capaz de tamanha determinação e de tamanha eficácia". "Lamentamos mesmo", continua ele, "que elas não tenham sido aplicadas a programas mais construtivos." A efetiva ação do Estado haitiano, sob o comando de Jean-Claude Duvalier, ao lado da USAID e de outros grupos internacionais, demonstrou, nesse caso, uma coordenação prática e eficaz que em si nada teve de disfuncional ou falida, mas revela um modo histórico de ação do Estado contra a sociedade (Trouillot, 1990). “De fato”, conclui Deshommes (2006, p. 65, tradução minha) em seu comentário, "se os responsáveis pelo projeto foram verdadeiramente eficazes quanto ao plano de 'Erradicação da Peste Suína', eles foram muito menos dedicados à parte de ‘Repovoamento'." Ti Tonton, um lavrador da região norte que entrevistei, comenta que pessoas "tentaram até esconder os porcos quando vieram matá-los. Mas depois o Estado

19 Ver o relato de Abdul Wahab, funcionário da USAID, no documentário A pig's tale (1997, 01min06s), de Leah Gordon e Anne Parisio. 
colocou pessoas para supervisionar se havia gente que ainda tivesse porcos crioulos. E mataram todos."

Foi voluntária a decisão de não levar à frente uma política de extermínio pontual. Enquanto alguns veterinários e sanitaristas, como os especialistas William Hess (1971, p. 25) e Jerry J. Callis (1980, p. 41), recomendavam a erradicação de grupos de porcos doentes ou expostos, o que de fato ocorreu foi um extermínio preventivo. Alguns meses depois do massacre teve início a etapa de repovoamento. Novas espécies de porcos chegavam aos povoados rurais haitianos vindos do Canadá e sobretudo dos EUA. Brancos, imensos e de difícil cuidado, em pouco tempo os animais estrangeiros ganharam o apelido de "príncipes de quatro patas" (Aristide, 2000, p. 14). Manufaturando não só uma doença, mas também os próprios animais, produziu-se também um novo sistema.

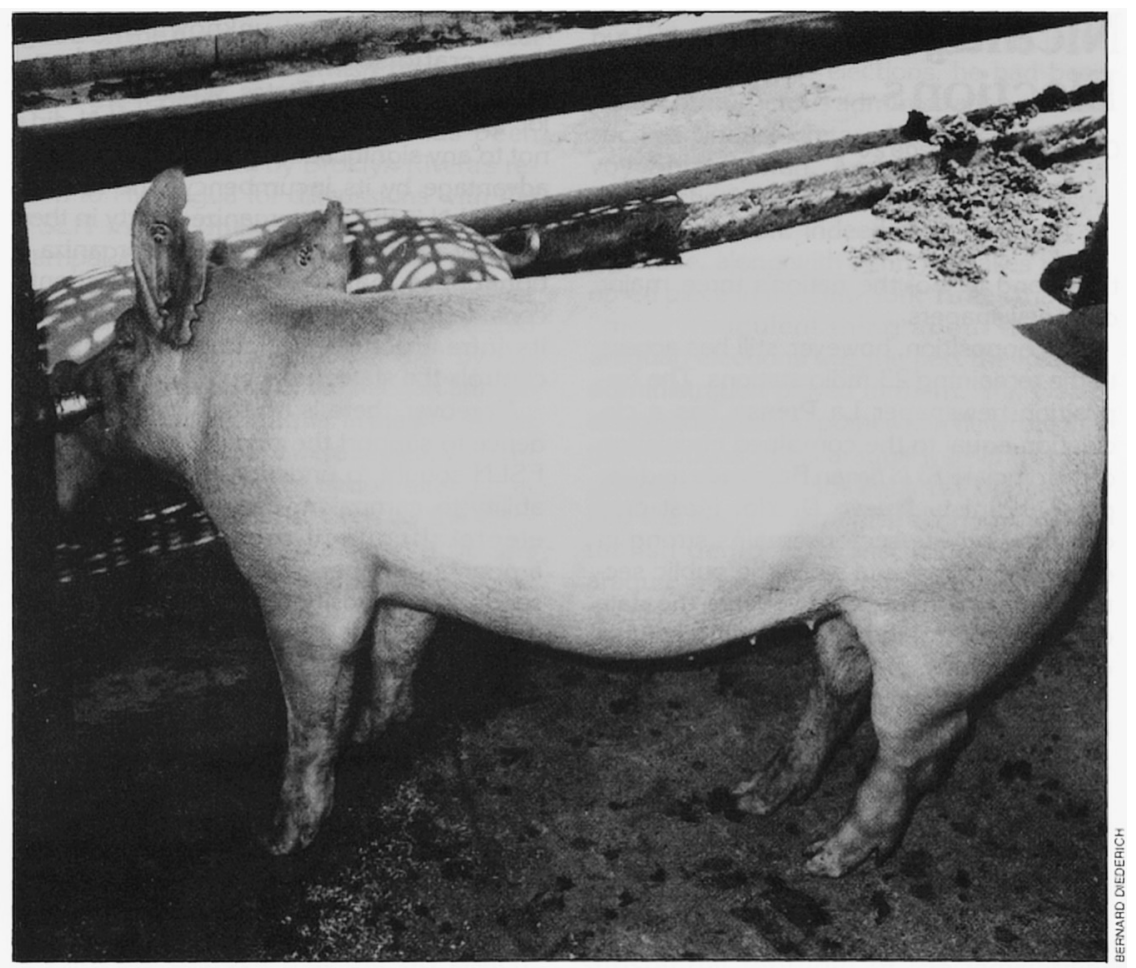

Figura 2. "Porco importado do estado de Iowa (EUA) bebendo água da torneira" (Diederich (1985, p. 17, tradução minha). 


\section{Sonhavam os especialistas com porcos assassinos?}

Nos documentos oficiais sobre o massacre, à necessidade de contenção da peste suína soma-se outra justificativa, talvez tão importante quanto a sanitária. Se os porcos crioulos são constantemente descritos como afeitos à vida solta, os espécimes hiperselecionados, grandes e de pele clara eram pouco autônomos, não suportavam o excesso de sol e requeriam maior cuidado e atenção. Por isso, foi necessária a difusão de outras formas de criação, menos embasadas em uma garantia de liberdade aos porcos e em uma proximidade dos animais com seres humanos e suas casas, e mais voltadas à intensificação do processo de confinamento. Para tanto, a chegada dos novos animais foi acompanhada de novas técnicas e tecnologias de criação, entendidas como mais "aperfeiçoadas", entre as quais a exigência de construção de chiqueiros especiais, cobertos e cimentados, e de uma alimentação especial baseada em rações importadas, tais como o farelo de trigo. Com efeito, o massacre ao buscar também a modernização das criações no país, por meio de um novo conjunto técnico, impunha uma nova representação sobre os animais.

Na região de Les Cayes, no sul do país, um relatório feito em 1987, sob encomenda da USAID (Grafton; Pognon; Robert, 1987), aponta para uma drástica queda no número de grupos domésticos que possuíam porcos, chegando a 7\% em uma amostra de 81 casas, de um total de 603 presentes na região. Antes do massacre, aproximadamente $94 \%$ das casas mantinham criações. ${ }^{20} \mathrm{O}$ estudo foi feito cinco anos após o massacre, o que revela uma insuficiência dos esforços de repovoamento de porcos com variedades estrangeiras. Os pesquisadores apontam também para uma diminuição no número total de animais por grupo doméstico, sendo que antes somavam em média 10 por casa, chegando a 2 no momento da pesquisa (Grafton; Pognon; Robert, 1987, p. 4). Ademais, os autores trazem estatísticas que corroboram a ideia de que os porcos serviam como

20 Se compararmos com os dados coletados pela equipe que trabalhou com Métraux (1951), das 147 famílias vivendo na região do vale do Marbial, na década de 1940, 92 possuíam porcos, ou 62\%. Desse total, 63 famílias eram católicas e 29 eram protestantes (Métraux, 1951, p. 186). O autor afirma, contudo, que, no período da pesquisa, as criações em geral estavam em número bastante reduzido devido à intensa seca que condenava a região (Métraux, 1951, p. 184), o que possivelmente levou muitas famílias a venderem seus animais num período anterior à chegada dos pesquisadores. 
reserva para gastos eventuais ou emergências, como casamentos, funerais e pagamentos de taxas escolares, com quase $100 \%$ dos entrevistados afirmando que os porcos eram "bancos" e ao redor de 93\% destacando sua importância como fonte de alimento e de renda. Quanto aos métodos de criação, o relatório traz a seguinte tabela (Grafton; Pognon; Robert, 1987, p. 9):

Tabela 1. Sistemas de criação (cf. Grafton, Pognon e Robert, 1987, p. 9, informações adicionais entre parênteses).

\begin{tabular}{|l|c|c|}
\hline \multicolumn{3}{|c|}{ Sistemas de criação de porcos empregados antes e depois do PEPPADEP } \\
\hline Tipo de sistema & Número de casas & \% de porcos de criação \\
\hline Antes do PEPPADEP & 1 & 1,3 \\
\hline Chiqueiro & 29 & 38,2 \\
\hline Parque (sem cobertura) & 75 & 98,7 \\
\hline Presos à corda & 44 & 57,9 \\
\hline Savana (relativamente livres) & 1 & 1,3 \\
\hline Outro & & 100 \\
\hline Presente & 6 & 0 \\
\hline Chiqueiro & 0 & 0 \\
\hline Parque & 0 & 0 \\
\hline Presos à corda & 0 & 0 \\
\hline Savana & 0 & \\
\hline Outro & & \\
\hline
\end{tabular}

A falta de estatísticas para o mesmo período em Milot impede uma análise comparativa mais detalhada. No entanto, os dados de Les Cayes revelam o impacto que o massacre teve em uma localidade específica e nos possibilita entender o que norteava as preocupações de especialistas no despontar daquele evento. Na tabela, nota-se a incidência dos dois principais modos de criação dos porcos antes do massacre: "presos à corda" (à la acorde) e o "sistema de savana" (savanne), com os animais relativamente livres nos terreiros e espaços domésticos. Por vezes, esses dois modos de criação eram combinados com o "parque" (parc ou 
chiqueiro sem cobertura). A necessidade de um novo sistema de criação é reiterada ao longo de todo o relatório, destacando que "muitas organizações do programa de repovoamento insistiram na construção de um sistema de criação aperfeiçoado [improved raising/rearing system] como precondição para que grupos domésticos ou associações recebessem os animais" (Grafton; Pognon; Robert, 1987, p. 8, tradução minha). Para um campesinato cujo capital era extremamente restrito e com uma de suas principais fontes de liquidez literalmente extinta, exigir que construíssem um chiqueiro aperfeiçoado como precondição para receberem novas espécies era, como definiu um morador de Milot, uma "verdadeira injustiça".

Nesse sentido, do ponto de vista dos agentes do massacre, o que parece estar por trás dessa medida é, ao lado da contenção da peste suína, um princípio modernizador nos esforços de repovoamento, observável também em outros contextos onde o extermínio de animais teve lugar, particularmente, nas décadas de 1970 e 1980, como a República Dominicana (Mark; Chain; Ellis, 1981) e o Brasil (Viana, 2004). A construção de chiqueiros cobertos e cimentados, algo exigido pelas autoridades, propiciaria, acreditavam os especialistas, um "melhor ambiente de criação" para os animais e, consequentemente, um aumento no valor dos porcos brancos se comparados aos de antigamente, $o$ que supostamente compensaria a grande quantidade de porcos de antes com um espécime de melhor qualidade (Grafton; Pognon; Robert, 1987). As exigências, contudo, não se restringiam somente a um chiqueiro moderno e a novas tecnologias de criação. Era necessário alimentar os novos animais com rações importadas e farelo de trigo, algo que implicava despesas que outrora inexistiam. Como nota madame Frank, durante a mesma conversa com Ti Tonton,

Os porcos que você está vendo, há pessoas que os têm, mas não é toda a gente. Porque, de fato, é preciso ter dinheiro para comprar farelo de trigo para dar aos animais. Mas com os outros porcos que tínhamos não havia isso. Você os amarrava, eles comiam ervas, coisas cruas, de tudo. Mas os que estão aí, é necessário ter dinheiro para comprar farelo de trigo [...] para fazê-los crescer.

Os porcos crioulos eram vistos como uma espécie de poupança e um retorno rápido poderia ser planejado a partir de uma alimentação dedicada à engorda ao longo de algumas semanas, conhecida como angrase, comumente feita por meio 
de uma dieta concentrada em abacates, como ilustra bem a pintura de Charles Saül que abre este artigo. Quando havia a necessidade de se empregar uma grande soma de dinheiro, prevista ou não, como em despesas escolares, funerárias, matrimoniais ou em caso de doenças, engordava-se o animal e em algumas semanas era possível vendê-lo, obtendo, assim, um retorno monetário rápido. Conforme o relato de um antigo morador de Samson, Michelet: "Um porco crioulo, primeiramente, era uma poupança bancária para os desafortunados [malere]." "Era sobre os porcos", continua Michelet, "que se assentava a economia da casa [lekonomi lakay]." Com a chegada dos porcos brancos, seu novo sistema de criação era extremamente desvantajoso, o que consequentemente levou a uma queda drástica nas possibilidades de existência das criações, tendo efeitos diversos na economia e na vida ritual dos camponeses. Havia ainda pessoas que encararam a medida como uma entre as tantas que, desde finais do século XIX, buscavam combater as práticas mágico-religiosas populares no país (Ramsey, 2011). Esse é, com efeito, um dos temas tratados pelo documentário A pig's tale (1997), de Leah Gordon e Anne Parisio, que segue a jornada de um rapaz em busca de um porco crioulo para um sacrifício exigido por um espírito herdado de sua família (lwa). Como mostra o filme, eliminando os porcos, animais-chave nos rituais de sacrifício e serviços (sèvis), avançava-se contra formas tradicionais de interação com entidades espirituais e outros seres mágicos do vodu. ${ }^{21}$

Nas palavras de madame Frank, uma interlocutora de campo que confirmava o argumento de outras pessoas com quem conversei, o problema era, de fato, o "sistema dos porcos crioulos". Rememorando o momento da chegada dos agentes que vieram dar fim às criações, ela assim continua seu relato:

Pelos grandes, nos deram 40 dólares haitianos, 20, pelos médios, e 5, pelos pequenos..$^{22}$ Eles matavam os porcos e nos davam dinheiro. Mas nos deixavam a

21 O que hoje conhecemos como vodu é um termo complexo que tenta abarcar uma série de fenômenos mágico-religiosos. Em meu trabalho de campo, e como frequentemente destacam outros pesquisadores, o termo apareceu poucas vezes para tratar dessa interação, sendo mais precisamente utilizado para definir batuques, danças e músicas. Sobre isso, ver ainda Richman (2005), Ramsey (2011), Bulamah (2015) e Bulamah e Dalmaso (2019).

22 Versões sobre os valores exatos variam, mas todas afirmam que o valor pago era significativamente menor do que se pagava em uma transação usual. Quanto à quantidade de porcos que havia no país na época do massacre, não há consenso entre estudiosos, com números variando entre 1 e 2 milhões. 
carne para que fizéssemos o que a gente quisesse. Eles mesmos é que matavam os porcos com um golpe de bastão. Eles não queriam o sistema desses porcos. Foi para nos enviarem os outros porcos que mataram os nossos. Diziam que tinham uma doença, que comiam muita coisa, muita porcaria. Foi o que os fez eliminar o nosso sistema para colocar o sistema deles.

O novo sistema exigia, então, uma atenção maior com o espaço e com a alimentação dos porcos, objetificando-os conforme o universo das criações industriais (Ingold, 2000). A categoria sistema é aqui operada como indício da diferença, de algo que, conforme elaboraram alguns interlocutores, tem um funcionamento, um jeito ou um modo distinto e, sobretudo, que possui uma história específica. São técnicas, práticas e representações que constituem um conjunto de interações historicamente construídas. Isso nos aproxima da noção de "sistema domesticatório" proposta por Jean-Pierre Digard (1999). Para o autor, que toma inspiração nas discussões da escola francesa de antropologia e história da técnica e nos trabalhos de Lévi-Strauss, a técnica implica uma tensão com a matéria, no caso, com os próprios animais (Digard, 1988, p. 46). Em sua definição, um sistema domesticatório é "tudo o que o homem investe na produção e utilização de animais: em ação técnica, em organização social, em pensamento [...], em representações, etc." (Digard, 1999, p. 14, tradução minha).

Nesse sentido, o sistema domesticatório é um fato social total, como aponta Jeremy Deturche (2017), pois recoloca a domesticação na sociedade, "não unicamente como simples prática provedora [...], mas nas suas dimensões de parentesco, política ou economia" (Deturche, 2017, p. 388). Porém, se a noção de sistema domesticatório avança ao olhar a domesticação como algo que não paira sobre a sociedade, e isso é um dos problemas da noção apontados por Deturche (2017. p. 397-398), ela supõe conjuntos mais ou menos estabelecidos entre, de um lado, humanos e, de outro, animais.

Na perspectiva dos moradores rurais do Haiti, por sua vez, o sistema dos porcos crioulos supunha exatamente um conjunto de interações no qual os animais não eram reduzidos a categorias coletivas, mas interagiam de modo criativo com humanos, espíritos e outros seres. Por isso, a substituição dos porcos crioulos pelos porcos brancos causou ruídos exatamente por não serem os mesmos porcos, como pode supor a noção de espécie propagada pelos veterinários e sanitaristas estrangeiros. A imposição do sistema dos porcos brancos 
buscou, de fato, estabelecer essa homogeneização a partir de uma outra visão do que eram os animais e de um outro conjunto técnico. Assim, tentava-se propor novas interações entre humanos e animais substituindo a liberdade por formas intensivas de confinamento. Entre humanos também não foi diferente: em algumas regiões, a introdução dos porcos foi realizada a partir de comitês de criação privados, o que produziu hierarquias entre moradores rurais de uma mesma vizinhança, estimulando conflitos, inveja e acusações de feitiçaria.23 Como resumiu um antigo criador de porcos de Milot, "os desafortunados não podem mais ter porcos, só gente rica".

Com o tempo os porcos brancos foram se adaptando e passaram a comer aquilo que encontravam, do mesmo jeito que os antigos, exigindo uma ração especial somente nos períodos de engorda. Porém, mesmo com essa adaptação, havia ainda algo a mais que diferenciava porcos brancos e crioulos, particularmente com relação aos comportamentos e hábitos alimentares. Senhor André, em sua descrição do massacre, assim revela: "Mataram os nossos porcos, mas os que nos enviaram é só destruição. Ou seja, eles comem tudo o que é das pessoas. Quando veem um pé de fruta-pão, puxam-no e comem. Puxam para cá e para lá. É só destruição." O descontrole da nova espécie de que fala senhor André diz respeito a esse outro sistema, pouco coordenado com a ecologia local, destruindo paisagens e plantas importantes para consumo, como a fruta-pão.

Há, ainda, uma diferença fundamental que configura a expressão maior do descontrole desse sistema: o fato de que os porcos brancos eram perigosos a outras criações e também às pessoas, particularmente às crianças. Se os porcos de antes viviam de modo mais livre, os brancos, "se você largá-los soltos", nota Ti Tonton, "eles podem comer gente. Sim, eles comem gente. Se você largar um porco e uma criança estiver no chão, ele a come."

23 Paul Farmer (1992, p. 14-15, grifo meu) relata o caso de Manno, um jovem recém-chegado ao vilarejo de Do Kay (nome fictício de uma localidade na região de Mirebalais), que, em 1982, começou a demonstrar sinais de uma nova doença: sida. Para muitas pessoas do vilarejo aquela, como tantas outras enfermidades, havia sido enviada (voye) por alguém motivado por inveja (jalouzi). Como descreve o antropólogo: "[Manno] was entrusted with a number of public - and remunerative - tasks, including taking care of the village's new water pump and the community pig project [...]. That an outsider would be granted such favors was deeply resented by some of the villagers, as became clear after Manno fell ill." Para uma descrição mais detalhada da chegada dos porcos brancos nessa mesma localidade, ver Farmer (1992, p. 38-41). 
Relatos sobre ataques de porcos a galinhas, pintinhos e crianças chegaram também às emissoras de rádio locais e nacionais, como na descrição do agrônomo Jean-Jacques Honorat em uma emissão de novembro de 1986, na Rádio Haïti-Inter (Destruction du cochon créole..., 1986, tradução minha):

Os porcos americanos importados possuem um modo de vida que não permite sua adaptação ao país e os próprios criadores de porcos não conseguem se adaptar a esses animais. [...] É preciso que se faça um estábulo em cimento numa grande instalação física, que os camponeses não possuem nem para a própria família. [...] Em várias partes do país, como na região de Miragoâne, por exemplo, os camponeses se desdobraram para fazer um estábulo com troncos de palmeira para os porcos importados. Mas o que ocorreu foi que os porcos comeram os troncos. Os camponeses não conseguiam dar-lhes a ração especial que os porcos demandavam e porcos são bichos grandes, por isso, eles comeram as madeiras, fugiram e começaram a comer as galinhas dos camponeses e até mesmo os moradores rurais, até mesmo o povo, as crianças. ${ }^{24}$

Tais observações sobre os porcos brancos fornecem uma dimensão ontológica importante relacionada à própria percepção do que é estrangeiro nesses povoados rurais: os porcos introduzidos se parecem com brancos (blan) e colocam em risco a vida das próprias crianças, tal como nas narrativas de sequestro e assalto que envolvem seres associados à maldade (mechanste), alguns deles sendo moun vini, pessoas vindas de outras regiões e, por isso, de fora do círculo familiar (Bastien, 1951, p. 55; Derby, 2015; Fiod, 2015; Marcelin, 2012; Thomaz, 2010). De fato, os malveyan ("figuras malignas"), particularmente os lougawou (lit. "lobisomens"), condensam um estado puro de maldade ao ponto de se assumirem como uma espécie de epítome do mal, sendo correntemente empregados em analogias cotidianas para se falar de algum desafeto ou inimigo. Moun ki manje moun ("pessoas que se alimentam de outras"), como definiu uma interlocutora, os lougawou são figuras metamorfas, seres meio-humano e meio-animal, que possuem uma fome predatória e desagregadora, circulando por povoados

24 Jennie Smith (2001, p. 30) afirma ter ouvido relatos similares na região de Grand'Anse durante seu trabalho de campo. 
e vilarejos particularmente durante a noite. ${ }^{25}$ Eles podem assumir a forma humana ou a de animais como cavalos, cachorros e sobretudo porcos, processo localmente conhecido como dedouble. Sua ação se dirige, particularmente, contra crianças ou mães que tiveram filhos recentemente, e consiste em adoecê-las, alimentando-se de seu sangue e consumindo-as até a morte. Que tais seres se metamorfoseiem e estejam a meio caminho entre natureza e cultura é um indício de seu poder. ${ }^{26} \mathrm{~A}$ desordem causada pela introdução dos novos porcos teve, assim, um amplo impacto na ecologia e na vida dos camponeses, pois os animais importados possuíam novas exigências e agiam de um modo distinto dos porcos crioulos. Como destacou Honorat na emissão de rádio, os porcos

25 Outras denominações locais de seres malignos são vijilans, chanpwèl e bizango. Ver também Fiod (2015), para um trabalho mais detido sobre esse tema. Rémy Bastien (1951, p. 55) nota que há uma interação de fundo entre lougawou e a mãe da criança que passa pela aceitação de uma dádiva, descrita por uma interlocutora do antropólogo como um sonho em que ela aceitou um doce oferecido pela figura maligna, colocando-a em uma relação de dívida com aquele ser. O romance de Gary Victor, Saison des porcs, centra-se na história de um detetive que investiga uma rede internacional de tráfico de sangue da qual participa um velho amigo seu que, ao envolver-se com figuras de poder e magia, começa a se transformar em um porco. Recentemente, houve uma votação no senado haitiano em que se discutiam leis anti-LGBT - denominados(as) masisi, no caso dos homens, e madivinèz, para as mulheres, ou simplesmente masi-madi-e após terem sido aprovadas, um dos senadores que apoiou a medida declarou em uma entrevista a uma rede nacional que a liberdade de pessoas LGBT se comparava aos excessos de liberdade dos lougawou e que, por isso, deveria ser restringida. Vídeos começaram a circular retratando os senadores que passaram a lei como "caçadores de lougawou". Cf. vídeo publicado por Michel Degraff em sua página pessoal no Facebook: https://www.facebook.com/michel.degraff/ videos/10155644461748872/ (acesso em 27/04/2018).

26 Diversas são as técnicas de proteção contra os lougawou. Entre elas estão os banhos de folhas em crianças e a administração de café e outras bebidas amargas à mãe e ao bebê. Isso serve, como me explicaram em Samson, para "deixar o sangue amargo" (fè san amè), causando repulsa a esses seres. Também o uso de "apelidos" (non gate) tem sua eficácia, pois o nome verdadeiro dá acesso à pessoa e lhe deixa suscetível a ataques. Não há alarde quando uma mulher fica grávida e o nome só é revelado algumas semanas depois do nascimento e para pessoas próximas. Publicamente, a criança recebe um apelido, normalmente em referência a algum elemento doméstico ou divino. Uma pessoa pode ainda ter vários apelidos, sendo comum assumir o nome, ou uma variação aproximativa, de um padrinho ou madrinha, além de acumular outros ao longo da vida. Esbocei uma análise dos nomes e sua relação com a proteção em um texto anterior que pode ser consultado em Bulamah (2013). Ademais, durante meu primeiro trabalho de campo, ao tentar inicialmente fazer genealogias das diferentes famílias de Samson, notava que os nomes iam variando e alguns se recusavam a me fornecer os "nomes de batismo" (non batistè), o que pode ter alguma relação com as próprias formas de interação entre camponeses e o Estado e as tensões fundiárias ao longo da história, revelando uma recusa às formas de codificação burocráticas e uma aproximação entre Estado e lougawou. 
brancos não se adaptaram ao país, assim como os criadores não se adaptaram a eles. O sistema era outro e, apesar das promessas e expectativas, as criações nunca retomaram a abundância dos tempos passados.

Para madame Frank, os porcos garantiam não só a possibilidade de reserva de liquidez, como também uma autonomia dos jovens com relação aos mais velhos. Como ela afirma,

se você tivesse um filho, como esses [apontando para os seus], poderia dar-lhe de presente alguns trocados. E ele poderia comprar um porquinho. E esse porco era quem colocava a criança na escola. Ele poderia vender o porco e, se fosse uma fêmea, quando tivesse filhotes, os venderia para comprar uniforme, sapatos, livro e mochila. A fêmea do porco tem sempre muitos filhotes. A criança poderia utilizá-los para pagar a escola, vendendo um ou dois porquinhos. Isso já não acontece mais. Com a ajuda dos porcos pequenos, as crianças poderiam adquirir coisas, dos avós, dos padrinhos, poderiam fazer de tudo. Os porcos ajudavam na escola e também na compra de um pedaço de terra. Você poderia ainda fazer um cartão do hospital. Se a criança ficasse doente e precisasse se tratar e você não tivesse dinheiro, você chamava alguém, venderia o porco e iria com a criança ao hospital. Mas agora, aqui, as crianças já não têm mais porcos. Esses porcos eram uma ajuda e tanto às pessoas.

O valor da autonomia para os camponeses e as tensões geracionais foram assuntos também tratados pelo antropólogo haitiano Rémy Bastien (1951), indo ao encontro do argumento de madame Frank. $O$ autor nota, numa discussão sobre o lugar do individualismo na sociedade camponesa, que desde cedo cultiva-se uma responsabilidade econômica desenvolvida dentro de uma estrutura social na qual a hierarquia é reinante. A autoridade paterna é, naquele universo, algo incontestável. Nesse sentido, destaca Bastien (1951, p. 37, tradução minha), "a tirania na educação coexiste com um verdadeiro liberalismo no que concerne o cultivo das terras...".

Se os porcos eram "bancos" ou "poupanças", o massacre atirou os camponeses em uma situação frágil na qual, para arcar com as exigências de gastos com cerimônias, morte ou doença tiveram que reestruturar suas vidas. Sem mais poder contar com a renda dos porcos, mudou-se todo o sistema. Crianças e jovens perderam a possibilidade de autonomia associada aos porcos e o resultado 
imediato foi o aumento da evasão escolar, que alcançou cifras entre 30\% e 50\%, segundo observadores da época (Aristide, 2000, p. 14-15; Deshommes, 2006, p. 68). ${ }^{27}$ Com isso, alterou-se também a relação dos moradores rurais com as plantas, com outros animais, com os alimentos e com a própria terra. Era o fim de um mundo ou, como destacou Michelet, "a morte do próprio país":

Foram os americanos que vieram com [os porcos estrangeiros]. Vieram com eles e disseram que nossos porcos transmitiam doença. Fizeram mesmo foi uma campanha depreciativa para jogar o país no abismo. Essa é uma campanha que temos que suportar enquanto haitianos e haitianas. Sabe? Isso é algo que nunca vai ter reparação. Pois do jeito que aqueles animais nos eram úteis, acreditávamos que [a substituição dos porcos] seria algo bom. Mas não há nada que seja bom. [...] Agora, os [porcos] que estão aqui não são iguais aos que possuíamos. Isso foi a morte do próprio país.

\section{Sujeitando porcos, sujeitando pessoas: evento e desordem}

"Os massacres se tornaram vitais" (Foucault, 1976, p. 180, tradução minha). É o que afirma Michel Foucault no último ensaio que compõe a História da sexualidade I: a vontade de saber. $\mathrm{O}$ tema dos massacres perpetrados por Estados modernos é, para o autor, uma das evidências da passagem de uma lógica de submissão a um poder soberano para uma lógica do biopoder, onde não mais somente o corpo, mas a vida de populações inteiras passa a ser o objeto das tecnologias e políticas de vigilância, sujeição e dominação. Interessava ao filósofo francês refletir sobre como formas liberais de governo incidem na gestão

27 Elizabeth Abbott (1988, p. 274-275) faz a seguinte observação sobre os efeitos da morte dos porcos: "School opening that October, the first after PEPPADEP's final eradication of the nation's pigs, revealed that [school] registration had plunged as much as 40 to 50 percent. Street vendors of cheap notebooks and pencils went hungry. The Lebanese and Syrian dry good merchants had unsold stockpiles of checkered cotton for the traditional Haitian school uniforms. Deschamps Printing Company's orders for Creole and French textbooks plummered. All over Haiti, children stayed at home, understanding that something was happening to them and that times were suddenly much harder." 
da saúde pública. É no ano da publicação de seu ensaio, 1976, que os primeiros casos de ebola começaram a colocar em alerta autoridades sanitárias internacionais (Keck, 2015, p. 227) e, apenas dois anos depois, tem início o massacre dos porcos na ilha de Espanhola.

Ali, a biopolítica se realizou também na gestão da vida animal e sua eliminação visava exatamente a garantia da existência de outra população. Se o poder soberano, para Foucault, se caracteriza pelo "fazer morrer e deixar viver", a biopolítica do Estado moderno é marcada pela possibilidade de "fazer viver e deixar morrer". No caso dos massacres, como nota o autor, "o círculo se fecha", as duas possibilidades se confundem e confluem em um contínuo marcado pela anatomopolítica que dá lugar à biopolítica. Como agentes de uma patogenia que se espalhava pelo globo, era necessário eliminá-los por completo. A facilidade com que isso ocorreu pode ser explicada pela combinação entre a efetiva ação do Estado e a razão imperialista estadunidense que se assentava em uma percepção biomédica hegemônica de que porcos compunham uma única espécie: seres sem história ou historicidade, que poderiam ser substituídos por outros espécimes, mais adaptados aos esquemas industriais de criação e produção de carne. Meros animais de confinamento, sujeitos à ordem social humana, ao controle reprodutivo e à utilização intensiva em busca de lucro.

Por sua história, sua ecologia e seu papel na constituição de uma autonomia camponesa, em estreita cooperação com os humanos, bem como por um ritual que fundou a nação, os porcos crioulos tinham grande valor entre camponeses e criadores em geral (Bulamah, 2019). Na leitura das autoridades nacionais, os porcos foram submetidos a um sacrifício, justificado como um "pan-americanismo" exemplar do governo e dos haitianos em geral. A destruição desse sistema pode ser entendida como uma medida de biossegurança que serviu à imposição de novas formas de sujeição animal, impactando, por sua vez, as próprias formas de sujeição de camponeses e moradores rurais ao Estado e a forças externas, produzindo endividamentos, avanços sobre as florestas para a produção de carvão vegetal e adensando formas de dependência e de dominação, tanto animais quanto humanas. Isso foi acompanhado por uma espetacularização do sacrifício, com imagens de animais mortos, de laboratórios campais e de caçadas circulando em periódicos e publicações especiais por todo o globo, mobilizando exércitos e brigadas em uma imensa guerra contra os porcos. 

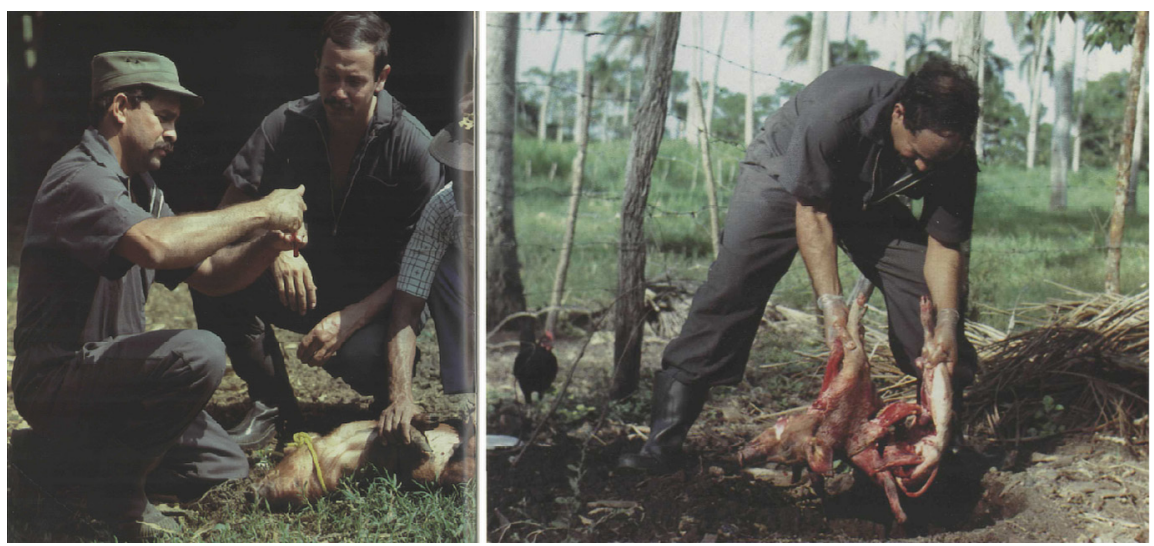

Figura 3. À esquerda: imagem sem título (Mark; Chain; Ellis, 1981, p. 4); à direita: “Em setembro de 1980, todos os porcos domésticos da República Dominicana foram massacrados" (Mark; Chain; Ellis, 1981, p. 15, tradução minha).

Para os moradores rurais, com a morte de seus porcos, o resultado foi a passagem a um mundo em que veterinários e sanitaristas eram os intérpretes de um novo projeto de natureza, no qual os animais deveriam ser eliminados dos círculos domésticos e novos métodos e técnicas de criação se assumiriam como artifícios de uma modernização a partir de novas formas de governo e controle, definindo uma nova geografia social. Surgiram rumores de porcos escondidos no norte do Haiti e na Ilha da Tartaruga, onde outrora piratas caçavam porcos ferais. Houve ainda tentativa de reintrodução de espécies crioulas de outras partes do Caribe, como a Jamaica, sobretudo após pressão de uma importante associação de camponeses e de órgãos ligados à Igreja Católica. Algo que foi logo descartado ou não passou de um esforço pontual, devido, sobretudo, ao excesso de burocracia e aos testes exigidos pelo Ministério da Agricultura do Haiti (Destruction du cochon créole..., 1986). A autonomia e a liberdade de antes foram suspensas e um novo sistema foi então imposto.

Nessa vida multiespécie, os porcos crioulos passaram por um sofrimento que foi sentido por todos. Não só enquanto metáfora de um país que vai à ruína, mas também metonimicamente por serem eles mesmos partícipes de um sistema que dependia de sua vida e de sua cooperação, estabelecido por meio de uma coevolução marcada por formas de mutualidade (Kropotkin, 1902). Sua 
ausência se fez e ainda se faz sentir por muitos. A história dos porcos ainda é contada e, mesmo em sua ausência, a vida camponesa em Milot é permeada pelos valores a que esses animais estavam associados e dos quais participaram ativamente na elaboração histórica. Mais do que isso, sua morte representou um passo a mais em direção à sujeição e ao controle das comunidades rurais por meio da demonstração efetiva do poder ditatorial e da espetacularização sacrificial do poder estadunidense, notável pela rápida circulação de imagens, de notícias e de discursos que celebravam o massacre. Com o passar dos anos, um novo sistema foi estabelecido, atingindo um equilíbrio, e hoje, em Milot, é possível ver pequenas criações, mas normalmente restritas a um ou dois animais. Contudo, as previsões de que a qualidade dos porcos compensaria a quantidade de antigamente não se cumpriram. Desafortunados (malere), como costumam referir-se coletivamente os moradores rurais haitianos, a morte dos porcos foi mais um entre os tantos episódios a que os pobres e camponeses do país tiveram de "suportar enquanto haitianos e haitianas".

\section{Referências}

10th COORDINATING Commitee meeting held at Peppadep-Delmas, 14-16 Nov. 1983. Relatório de reunião. Port-au-Prince: [s.n.], 1983.

ABBOTT, E. Haiti: the Duvaliers and their legacy. London: Hale, 1988.

ANDRIOLLI, C. S. Sob as vestes de Sertão Veredas, o Gerais: "Mexer com criação" no Sertão do IBAMA. 2011. Tese (Doutorado em Antropologia Social) - Instituto de Filosofia e Ciências Humanas, Universidade Estadual de Campinas, Campinas, 2011.

ARISTIDE, J.-B. Eyes of the heart: seeking a path for the poor in the age of globalization. Monroe: Common Courage Press, 2000.

BALASSA, B. Bibliography of African swine fever, 1921-1965. Greenport: U.S. Dept. of Agriculture, Agricultural Research Service, Animal Disease and Parasite Research Division: Plum Island Animal Disease Laboratory, 1966.

BASTIEN, R. La familia rural haitiana, Valle de Marbial. México: Libra, 1951.

BULAMAH, R. C. O cultivo dos comuns: parentesco e práticas sociais em Milot, Haiti. 2013. Dissertação (Mestrado em Antropologia Social) - Instituto de Filosofia e Ciências Humanas, Universidade Estadual de Campinas, Campinas, 2013. 
BULAMAH, R. C. Um lugar para os espíritos: os sentidos do movimento desde um povoado haitiano. Cadernos Pagu, n. 45, p. 79-110, 2015.

BULAMAH, R. C. Ruínas circulares: vida e história no norte do Haiti. 2018. Tese (Doutorado em Antropologia Social) - Instituto de Filosofia e Ciências Humanas, Universidade Estadual de Campinas, Campinas, 2018.

BULAMAH, R. C. De marrons a kreyòl: a chegada dos porcos ao Caribe e a gênese do campesinato haitiano (1492-1804). In: REUNIÃO DE ANTROPOLOGIA DA CIÊNCIA E DA TECNOLOGIA, 7., 2019, Florianópolis. Anais... Florianópolis: Universidade Federal de Santa Catarina, 2019. p. 1-27.

BULAMAH, R. C.; DALMASO, F. Revisitando o vodu: interações e movimentos entre humanos e espíritos em dois contextos haitianos. Campos, v. 20, n. 1, p. 1-14, 2019.

CALLIS, J. J. African swine fever: a review. In: INTER-AMERICAN MEETING AT THE MINISTERIAL LEVEL ON FOOT-AND-MOUTH DISEASE AND ZOONOSES CONTROL, 12., 17-10 April 1979, Willemstead, Curacao. Animal health in the Americas, 1979: African swine fever: animal health laboratories and their support of health care programs in rural areas: proceedings... Washington, D.C.: Pan American Health Organization: Pan American Sanitary Bureau: Regional Office of the World Health Organization, 1980. p. 39-42.

CASSIDY, R.; MULLIN, M. (ed.). Where the wild things are now: domestication reconsidered. Oxford: Berg, 2007.

CROSBY, A. W. Ecological imperialism: the biological expansion of Europe, 900-1900. Cambridge: Cambridge University Press, 1986.

DERBY, L. Imperial idols: French and United States revenants in Haitian Vodou. History of Religions, v. 54, n. 4, p. 394-422, 2015.

DESHOMMES, F. Haïti la nation écartelée: entre "plan américain" et projet national. Port-au-Prince: Cahiers Universitaires, 2006.

DESTRUCTION DU COCHON CRÉOLE: les efforts de Caritas pour remplacer le cochon créole. Radio Haiti, nov. 1986. Disponível em: http://radiohaitilives.com/fr/ enregistrements/destruction-du-cochon-creole-les-efforts-de-caritas-pour-remplacer-le-cochon-creole-novembre-1986/. Acesso em: 28 mar. 2017.

DESTRUCTION OF PIGS urged to halt fever in Rome area. The New York Times, New York, p. 28, 12 abr. 1967.

DETURCHE, J. A “genética” do cotidiano: seleção e reprodução na criação de vacas Montbéliarde (França). In: SAUTCHUK, C. (org.). Técnica e transformação: perspectivas antropológicas. Rio de Janeiro: ABA Publicações, 2017. p. 379-400. 
DIEDERICH, B. Swine fever ironies: the slaughter of the Haitian black pig. Caribbean Review, v. 14, n. 1, p. 16-17, 1985.

DIGARD, J.-P. Jalons pour une anthropologie de la domestication animale. L'Homme, v. 28, n. 108, p. 27-58, 1988.

DIGARD, J.-P. Les français et leurs animaux. Paris: Fayard, 1999.

EDITORIAL: bon appétit, messieurs!. Radio Haiti, 20 oct. 1980. Disponível em: http:// radiohaitilives.com/fr/enregistrements/editorial-bon-appetit-messieurs-20-octobre-1980. Acesso em: 15 jan. 2017.

FARAGE, N. De ratos e outros homens: resistência biopolítica no Brasil moderno. In: LÉPINE, C.; SCHWARCZ, L.; HOFBAUER, A. (ed.). Manuela Carneiro da Cunha: o lugar da cultura e o papel da antropologia. Rio de Janeiro: Beco do Azougue, 2011. p. 279-309.

FARMER, P. AIDS and accusation: Haiti and the geography of blame. Berkeley: University of California Press, 1992.

FEW, M.; TORTORICI, Z. (ed.). Centering animals in Latin American history. Durham: Duke University Press, 2013.

FIOD, A. Lougawou: feitiços, famílias e crianças em Siwvle, Haiti. 2015. Dissertação (Mestrado em Antropologia Social) - Museu Nacional, Universidade Federal do Rio de Janeiro, Rio de Janeiro, 2015.

FOUCAULT, M. Histoire de la sexualité. Paris: Gallimard, 1976.

GARCIA, U. Karawara: a caça e o mundo dos Awá-Guajá. 2011. Tese (Doutorado em Antropologia Social) - Faculdade de Filosofia, Letras e Ciências Humanas, Universidade de São Paulo, São Paulo, 2011.

GRAFTON, R.; POGNON, H.; ROBERT, L. The raising of pigs before and after PEPPADEP. Les Cayes: USAID: University of Arkansas: Winrock International: Ministère de l'Agriculture d'Haïti, 1987. Disponível em: http://pdf.usaid.gov/pdf_docs/PNABC219. pdf. Acesso em: 15 maio 2019.

GROUPE DE RECHERCHE POUR LE DÉVELOPPEMENT. Peste porcine africaine, cochons et paysans en Haïti. Le Nouvelliste, Port-au-Prince, 27 fev. 1981.

HESS, W. R. African swine fever virus. New York: Springer-Verlag, 1971.

HORIZONTES ANTROPOLÓGICOS. Porto Alegre, ano 23, n. 48, maio/ago. 2017.

INGOLD, T. From trust to domination: an alternative history of human-animal relations. In: INGOLD, T. The perception of the environment: essays on livelihood, dwelling and skill. London: Routledge, 2000. p. 61-76. 
KECK, F. Liberating sick birds: poststructuralist perspectives on the biopolitics of Avian influenza. Cultural Anthropology, v. 30, n. 2, p. 224-235, 2015.

KELLY, J. D.; KAPLAN, M. Represented communities: Fiji and world decolonization. Chicago: The University of Chicago Press, 2001.

KROPOTKIN, P. Mutual aid: a factor of evolution. New York: McClure Phillips \& Co., 1902.

LATOUR, B. The pasteurization of France. Cambridge: Harvard University Press, 1988.

LÉVI-STRAUSS, C. Somos todos canibais. Verve, v. 9, p. 13-21, 2006.

MALMQUIST, W. A.; HAY, D. Hemadsorption and cytopathic effect produced by African Swine Fever virus in swine bone marrow and buffy coat cultures. American Journal of Veterinary Research, v. 21, p. 104-108, 1960.

MANSO RIBEIRO, J. et al. Peste porcine provoquée par une souche différente (Souche $\mathrm{L}$ ) de la souche classique. Bulletin de l'Office international des épizooties, v. 50, p. 516-534, 1958.

MARCELIN, L. H. In the name of the nation: blood symbolism and the political habitus of violence in Haiti. American Anthropologist, v. 114, n. 2, p. 253-266, June 2012.

MARK, L.; CHAIN, P.; ELLIS, K. African swine fever. Washington, D.C.: U.S. Dept. of Agriculture, Animal and Plant Health Inspection Service (USDA): Agency for International Development (USAID): Food and Agriculture Organization (FAO), 1981.

MENDES SERRÃO, U. African swine fever in Brazil. In: INTER-AMERICAN MEETING AT THE MINISTERIAL LEVEL ON FOOT-AND-MOUTH DISEASE AND ZOONOSES CONTROL, 12., 17-10 April 1979, Willemstead, Curacao. Animal health in the Americas, 1979: African swine fever: animal health laboratories and their support of health care programs in rural areas: proceedings... Washington, D.C.: Pan American Health Organization: Pan American Sanitary Bureau: Regional Office of the World Health Organization, 1980. p. 43-54.

MÉTRAUX, A. Making a living in the Marbial valley(Haiti). Paris: Unesco, 1951.

MINTZ, S. W. Sweetness and power: the place of sugar in modern history. New York: Penguin, 1985.

MITCHELL, T. Rule of experts: Egypt, techno-politics, modernity. Berkeley: University of California Press, 2012.

MONTGOMERY, R. E. On a form of swine fever occurring in British East Africa (Kenya Colony). Journal of Comparative Pathology and Therapeutics, v. 34, p. 159-191, 1921.

MOURA, J. et al. An analysis of the 1978 African swine fever outbreak in Brazil and its eradication. Bulletin de l'Office international des épizooties, v. 29, n. 3, p. 549-563, 2010. 
MURRAY, G. The Haitian pig slaughter. An Island Luminous, [2016]. Disponível em: http://islandluminous.fiu.edu/part10-slide12.html. Acesso em: 10 mar. 2017.

NEIBURG, F. A true coin of their dreams: imaginary monies in Haiti. HAU: Journal of Ethnographic Theory, v. 6, n. 1, p. 75-93, 2016.

PALMIÉ, S.; SCARANO, F. The Caribbean: a history of the region and its peoples. Chicago: The University of Chicago Press, 2011.

PEREIRA, L. P. Os sacrifícios da carne: a morte do gado e a produção dos banquetes nas folias de Urucuia, MG. Religião e Sociedade, v. 32, n. 1, p. 71-96, 2012.

A PIG'S TALE. Direção e produção: Leah Gordon e Anne Parisio. [S.1.]: Parisio Production, 1997. color. $52 \mathrm{~min}$.

PLUMMER, B. G. The golden age of tourism: US influence in Haitian cultural and economic affairs, 1934-1971. Cimarrón: New Perspectives on the Caribbean, v. 2, n. 3, p. 49-63, 1990.

R@U: REVISTA DE ANTROPOLOGIA DA UFSCAR. São Carlos, v. 7, n. 1, jan./jun. 2015.

RAMSEY, K. The spirits and the law: Vodou and power in Haiti. Chicago: The University of Chicago Press, 2011.

RICHMAN, K. E. Migration and Vodou. Gainiesville: University Press of Florida, 2005.

SÁNCHEZ BOTIJA, C.; POLO JOVER, F. Informe sobre algunos aspectos de la peste porcina africana en España en 1964. Bulletin de l'Office international des épizooties, v. 62, p. 945-952, 1964.

SÁNCHEZ DÍAZ, O. Report on the status of African swine fever in the Dominican Republic. In: INTER-AMERICAN MEETING AT THE MINISTERIAL LEVEL ON FOOT-AND-MOUTH DISEASE AND ZOONOSES CONTROL, 12., 17-10 April 1979, Willemstead, Curacao. Animal health in the Americas, 1979: African swine fever: animal health laboratories and their support of health care programs in rural areas: proceedings... Washington, D.C.: Pan American Health Organization: Pan American Sanitary Bureau: Regional Office of the World Health Organization, 1980. p. 55-59.

SAUTCHUK, C. E. Os antropólogos e a domesticação: derivações e ressurgências de um conceito. In: SEGATA, J.; RIFIOTIS, T. (org.). Políticas etnográficas no campo da ciência e das tecnologias da vida. Porto Alegre: Ed. UFRGS, 2018. p. 85-108.

SCOTT, D. Omens of adversity: tragedy, time, memory, justice. Durham: Duke University Press, 2014.

SEVERO, R. Impoverished Haitians sell plasma for use in the U.S. The New York Times, New York, p. 2, 28 jan. 1972. Disponível em: https://www.nytimes.com/1972/01/28/archives/impoverished-haitians-sell-plasma-for-use-in-the-us.html. Acesso em: 15 jan. 2017. 
SMITH, J. M. When the hands are many: community organization and social change in rural Haiti. Ithaca: Cornell University Press, 2001.

SORDI, C. Guerra ao javali: invasão biológica, feralização e domesticação nos campos sulinos. R@U: Revista de Antropologia da UFSCar, São Carlos, v. 7, n. 1, p. 59-77, jan./jun. 2015.

SORDI, C.; LEWGOY, B. Javalis no Pampa: invasões biológicas, abigeato e transformações da paisagem na fronteira brasileiro-uruguaia. Horizontes Antropológicos, Porto Alegre, ano 23, n. 48, p. 75-98, maio/ago. 2017.

THOMAS, K. Homem e o mundo natural: mudanças de atitude em relação às plantas e aos animais (1500-1800). Tradução João Roberto Martins Filho. São Paulo: Companhia das Letras, 1996.

THOMAZ, O. R. O terremoto no Haiti, o mundo dos brancos e o Lougawou. Novos Estudos CEBRAP, n. 86, p. 23-39, 2010.

TORRIENTE, A. P. Mar nuestro / Manteca. San Juan: Fragmento Imán Editores, 2005.

TROUILLOT, M.-R. Haiti, state against nation: the origins and legacy of Duvalierism. New York: Monthly Review, 1990.

VANDER VELDEN, F. F. Inquietas companhias: sobre os animais de criação entre os Karitiana. São Paulo: Alameda, 2012.

VIANA, F. C. História e memória da peste suína africana no Brasil, 1978-1984: passos e descompassos. 2004. Tese (Doutorado em Ciência Animal) - Escola de Veterinária, Universidade Federal de Minas Gerais, Belo Horizonte, 2004.

VIBRANT. Brasília, v. 13, n. 2, July./Dec. 2016.

WOLF, E. A Europa e os povos sem história. Tradução Carlos Eugênio Marcondes. São Paulo: Edusp, 2002.

WOODS, A. A manufactured plague?: the history of foot and mouth disease in Britain. London: Earthscan, 2004.

Recebido: 19/05/2019 Aceito:14/11/2019 | Received:5/19/2019 Accepted:11/14/2019 